\title{
Characterization and Fabrication of Pb-Based Perovskites Solar Cells under Atmospheric Condition and Stability Enhancement
}

\author{
Shah Sultan Ashrafi'1,2, M. K. Hossain"1,3, Md. Momanul Islam ${ }^{1,4}$, M. U. Hossain'1, S. M. Fahad ${ }^{1,2}$, \\ M. Kamrujjaman', Md. Maidul Islam Masum¹, F. Ahmed"1, M. A. Hossain1, \\ Mohammad Obaidur Rahman ${ }^{1}$
}

\author{
${ }^{1}$ Department of Physics, Jahangirnagar University, Dhaka, Bangladesh \\ ${ }^{2}$ Department of Chemistry and Physics, Gono University, Dhaka, Bangladesh \\ ${ }^{3}$ Department of Physics, University of California, Merced, CA, USA \\ ${ }^{4}$ Department of Physics, Dhaka College, Dhaka, Bangladesh \\ ${ }^{5}$ Department of Physics, Hajee Mohammad Danesh Science \& Technology University, Dinajpur, Bangladesh \\ Email: sultanashrafi63@gmail.com
}

How to cite this paper: Ashrafi, S.S., Hossain, M.K., Islam, Md.M., Hossain, M.U., Fahad, S.M., Kamrujjaman, M., Masum, Md.M.I., Ahmed, F., Hossain, M.A. and Rahman, M.O. (2020) Characterization and Fabrication of $\mathrm{Pb}$-Based Perovskites Solar Cells under Atmospheric Condition and Stability Enhancement. Advances in Materials Physics and Chemistry, 10, 282-296. https://doi.org/10.4236/ampc.2020.1011022

Received: September 27, 2020

Accepted: November 24, 2020

Published: November 27, 2020

Copyright $\odot 2020$ by author(s) and Scientific Research Publishing Inc. This work is licensed under the Creative Commons Attribution-NonCommercial International License (CC BY-NC 4.0). http://creativecommons.org/licenses/by-nc/4.0/ (c) (i) (\$) Open Access

\begin{abstract}
Optimization of Graphene concentration in optoelectronic properties has been studied which leads to progressive stability based on Graphene- $\mathrm{CH}_{3} \mathrm{NH}_{3} \mathrm{PbI}_{3}$ employing nanoparticles perovskites solar cells in this work. $\mathrm{CH}_{3} \mathrm{NH}_{3} \mathrm{PbI}_{3}$ wafer-based hetero-junction solar cells were developed under atmospheric conditions using Graphite as a hole transport layer ( $\mathrm{HTL}$ ) and $\mathrm{TiO}_{2}$ as an electron transport layer (ETL). In particular a considerable enhancement in power conversion efficiency (PCE $<0.01 \%$ ) has been realized using optimum Graphene concentration $(0.05 \mathrm{~g} / \mathrm{ml})$. The charge injection rate is radically faster for the particular Graphene composition than the pristine perovskites, which exposes ephemeral absorption in near to UV range. Graphene incorporation increased the average crystallite size and reduced the band gap 1.32 $\mathrm{eV}$ in the visible range. The expensive metals such as $\mathrm{Ag}$ and $\mathrm{Au}$ have been replaced by simple ITO, which tremendously reduces the fabrication cost of the PSCs. The fabricated devices were exposed to high conservation stability without cell encapsulation ambient condition for 150 days to show excellent stability.
\end{abstract}

\section{Keywords}

Graphene, Perovskites, Hetero-Junction, Conversion Efficiency, Atmospheric

\section{Introduction}

One of the most promising materials, lead halide perovskites have been demon- 
strated for next-generation photovoltaic and light-harvesting application [1] [2]. Organic-Inorganic lead halide perovskites have been attracted great interest from many researchers due to tremendous improvement of power conversion efficiency (PCE), 3.9\% to more than 22\% within short research of time 2009 to 2020 [3] [4] [5]. Currently, mixed organic-inorganic halide perovskites have materialized as a novel class of light-absorbing material for highly efficient solar cells with established efficiency of $20.1 \%$. Some of the optoelectronic properties have been studied like strong absorption coefficients, optical band gap, hybrid perovskite-based absorbers, flexible and low cost in earlier reports [6] [7] [8]. Despite the high record PCEs due to applying specialized conditions, the present world requires progressive stability of photovoltaic cells and reduces fabrication cost [9] [10]. The single cation perovskites such as formamidinium lead halide $(\mathrm{FAPbX})$, methylammonium lead halide $\left(\mathrm{MAPbX}_{3}, \mathrm{MA}=\mathrm{CH}_{3} \mathrm{NH}_{3}, \mathrm{X}=\mathrm{Br}\right.$ or $\mathrm{Cl}$ or I) reveal relatively low stability under ambient condition while Mixed perovskites are robust against experience to moisture and heat [11] [12]. Graetzel et al. [13] have demonstrated PSCs efficiency more than 20\% with MA/FA mix cations where Seok et al. [14] have investigated $\left(\mathrm{MAPbBr}_{3}\right)_{\mathrm{x}}$ and $\left(\mathrm{FAPbI}_{3}\right)_{\mathrm{x}}$ compounds in PSCs in the compositional engineering. Recently, Tan and his coworkers realized highly efficient perovskites device using triple cation based on colloidal nano-crystal chlorine capped $\mathrm{TiO}_{2}\left(\mathrm{Cl}-\mathrm{TiO}_{2}\right)$ layer in planar architecture [15] [16] [17]. In the ambient atmosphere, Triple (Cs/FA/MA) cation based perovskite materials reveal exceeding power conversion efficiency $20 \%$ in a long time stable performance [18] [19]. The planar inverted structure is the adoption of the bulk heterojunction organic solar cell structure in PSCs while the main concern in the normal planar structure PSCs is hysteresis [20]. Using a nitrogen-filled glove box in the laboratory highly durable performance of triple cation perovskite has been demonstrated by atmosphere-controlled crystallization processes whereas in the large scale industrialization [21] [22] [23]. Lead halide perovskites are a high sensitivity to atmospheric conditions, especially humidity. To increase the electron withdrawal from the perovskite to the compact $\mathrm{TiO}_{2}$ for the normal (mesostructured and planar) perovskite solar cell structure graphene oxide concentration and other solution procedure able graphene derivatives have been reduced. Improving the operational stability of PSCs and the positive function of graphene-based materials in an approach to raising the grain size of the perovskite absorber have been investigated by utilizing it as the hole transport layer (HTL) [24] [25] [26]. As well as its low-cost solution-phase production techniques, its optical, incomparable electrical and physical properties have been developed. An efficient approach to improve the photodetection performance using the hybridization of graphene with a gain material or the formation of a hetero-structure has been showing [27] [28]. Highly enhanced photoconductive gain has been demonstrated by the mixtures of graphene with quantum dots or $\mathrm{TiO}_{2}$. Many optoelectronic and photonic applications can be confirmed such as a light-emitting diode, random lasing and photodetection using these unique photoelectrical properties [29] [30] [31]. 
Peng You et al. [32] reported by the chemical vapor deposition (CVD) method as top transparent electrodes multilayer graphene prepared where the conductivity of graphene was improved by coating a thin layer of poly-(3,4-ethylene dioxythiophene): poly(styrene sulfonate) (PEDOT:PSS). Do-Hyun Kwak et al. [33] demonstrated hybrid graphene-CsPbBr $\mathrm{I}_{\mathrm{x}} \mathrm{NCs}$ which highly photosensitivity and reported directivity of $2.4 \times 10^{16}$ jones at incident power of $0.07 \mu \mathrm{Wcm}^{-2}$ under $405 \mathrm{~nm}$ which have potential photodiode applications. Besides having high-quality railing properties to gases and water so that the thickness of the coating does not decelerate charge transfer and suspend solar cells' performance to select elements that have far beyond the ground electron and hole conductivity [34] [35]. We demonstrate the fabrication and characterization of general formula $\mathrm{MAPbI}_{3}$ and $\mathrm{G}-\mathrm{MAPbI}_{3}$ perovskites with the enterprise of investigating the thin film deposition for studying the photovoltaic properties to discover their potential as a light harvester in commercial applications of perovskites solar cells. Graphene is a required material to recover the lead oxidization and improve the optical absorption in the UV-visible range in a particular concentration (G: $0.05 \mathrm{~g} / \mathrm{mole}$ ) of it. Thus, we optimize Graphene composition with pristine perovskites to develop optoelectronic properties and investigate the stability of photovoltaic cell performance for further improvement of commercial application.

\section{Results and Discussion}

\subsection{Characterization of $\mathrm{CH}_{3} \mathrm{NH}_{3} \mathrm{PbI}_{3}$ and Graphene- $\mathrm{CH}_{3} \mathrm{NH}_{3} \mathrm{PbI}_{3}$}

The as crystallized lead iodide perovskite, Graphene- $\mathrm{CH}_{3} \mathrm{NH}_{3} \mathrm{PbI}_{3}$ on glass and powder crystal were fully characterized avoiding misconception in this manuscript where iodide leads source for the crystal formation, but performs as crystallization and enters in the lattice of the perovskite. The crystal structure and purity of the synthesized $\mathrm{MAPbI}_{3}\left(\mathrm{CH}_{3} \mathrm{NH}_{3} \mathrm{PbI}_{3}\right)$ and G-MAPbI${ }_{3}$ nanoparticles were determined by powder X-Ray diffraction (XRD, Diffractometer at WMSRC, JU, Bangladesh). The intensities and positions of observed diffraction peaks are good agreement and the resolution of the main diffraction peaks reflects the good crystallization of the $\mathrm{MAPbI}_{3}$ nanoparticles. Figure 1(a) and Figure 1(b) show powder and thin film XRD peaks of synthesized Methyl ammonium Lead Iodide and graphene incorporated Methyl ammonium Lead Iodide. Major planes (110) and (220) are indexed at angle $14.08^{\circ}$ and $28.33^{\circ}$ first and second-order peak maxima respectively and few peaks are assigned to the glass substrate which confirmed the monoclinic lattice system (Table 1 ). Crystallinity and volume of the unit cell are augmented with the graphene incorporation (G: $0.05 \mathrm{~g} / \mathrm{mole}$ ) $94.65 \mathrm{~nm}$ to $113.43 \mathrm{~nm}$ for powder and $117.15 \mathrm{~nm}$ to $141.94 \mathrm{~nm}$ (From XRD by Scherer Equation) for a thin film which was presented using full-width half maxima (FWHM) which accumulated uniformly due to sharp peaks achieved. Only a few pinholes and with quite bulky grains were found with compact perovskite layer in the top view of perovskite films (Figure 2(a)). 


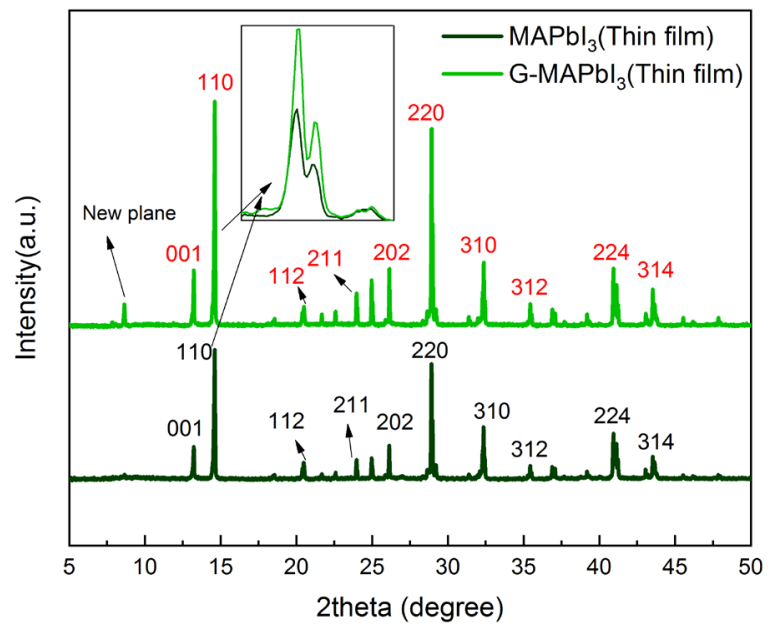

(a)

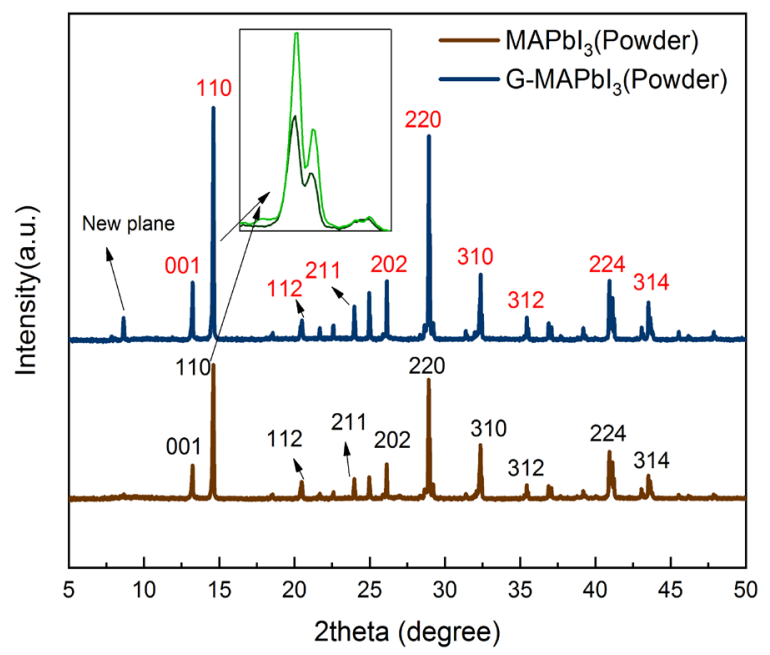

(b)

Figure 1. (a) Comparison of powder crystal X-ray diffraction of Methylammonium lead iodide $\left(\mathrm{MAPbI}_{3}\right)$ and graphene incorporated Methylammonium lead iodide $\left(\mathrm{G}-\mathrm{MAPbI}_{3}\right)$ and (b) Comparison of thin-film X-ray diffraction of Methylammonium lead iodide $\left(\mathrm{MAPbI}_{3}\right)$ and graphene incorporated Methylammonium lead iodide (G-MAPbI ${ }_{3}$ ).

Table 1. Lattice parameters and crystal structure of perovskites.

\begin{tabular}{ccccccc}
\hline Formula & $\begin{array}{c}\text { Crystal } \\
\text { System }\end{array}$ & $\begin{array}{c}\text { a } \\
{[\AA]}\end{array}$ & $\begin{array}{c}\text { b } \\
{[\AA]}\end{array}$ & $\begin{array}{c}\text { c } \\
{[\AA]}\end{array}$ & $\beta[\mathrm{deg}]$ & $\begin{array}{c}\text { The volume } \\
\text { of unit cell, } \\
\mathrm{V}\left(\AA^{3}\right)\end{array}$ \\
\hline $\begin{array}{c}\text { Thin-film } \mathrm{MAPbI}_{3} \\
\begin{array}{c}\text { Thin-film } \\
\text { G-MAPbI }\end{array}\end{array}$ & Monoclinic & 13.54 & 13.66 & 4.24 & 98.3 & 776.32 \\
$\begin{array}{c}\text { Powder } \mathrm{MAPbI}_{3} \\
\text { Powder G-MAPbI }\end{array}$ & Monoclinic & 12.82 & 6.03 & 14.15 & 97.32 & 1084.9 \\
\hline
\end{tabular}

*(Using XRD data by full proof software). 

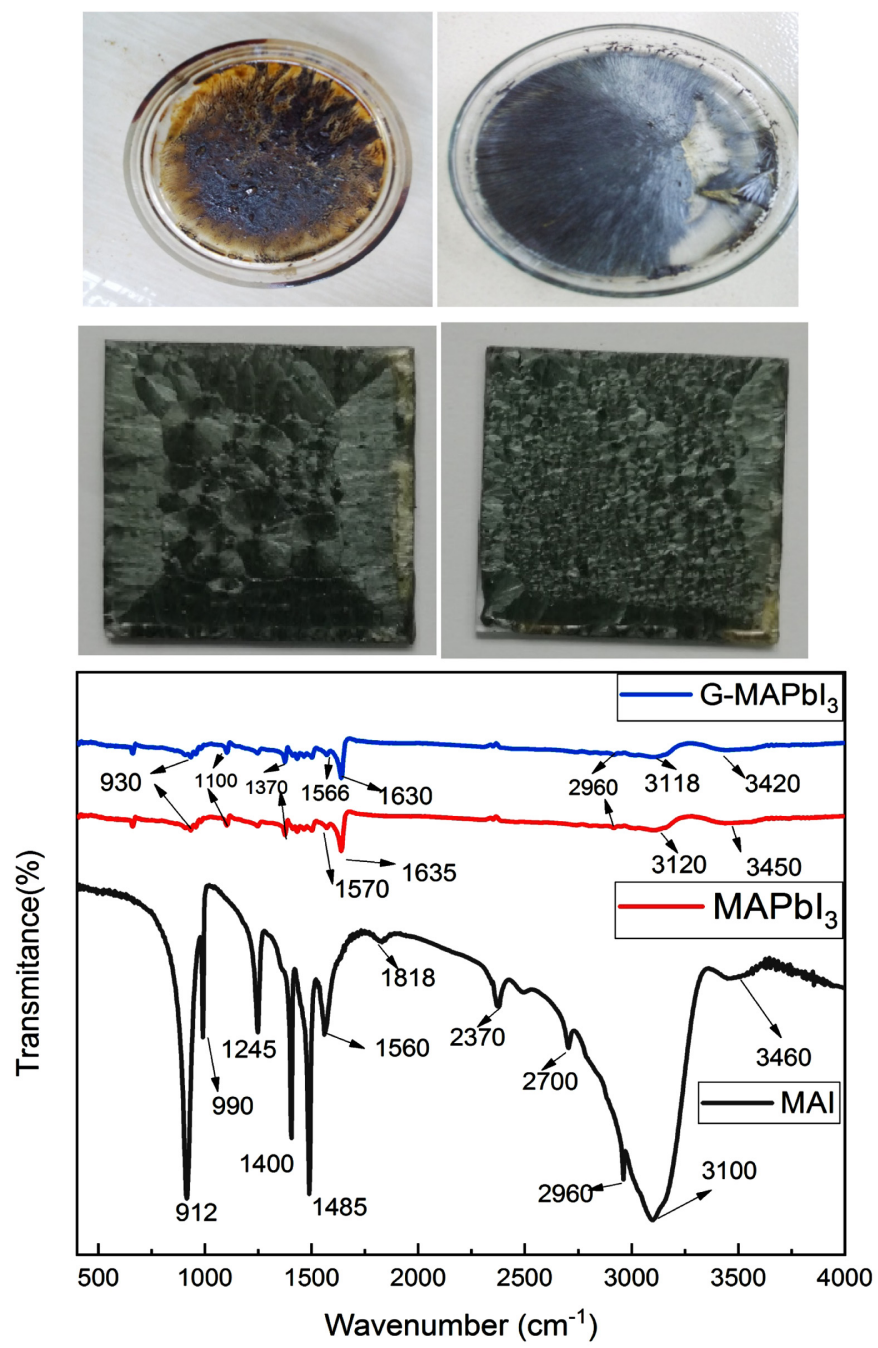

Figure 2. (a) Powder crystal of Methylammonium lead iodide $\left(\mathrm{MAPbI}_{3}\right)$, (b) Graphene incorporated Methylammonium lead iodide $\left(\mathrm{G}-\mathrm{MAPbI}_{3}\right)$, (c) Optical Image of Methylammonium lead iodide $\left(\mathrm{MAPbI}_{3}\right)$ thin film (Thickness $2 \mu \mathrm{m}, 2.5 \mathrm{~cm} \times 2.5 \mathrm{~cm}$ on glass substrate), (d) Optical Image of graphene incorporated Methylammonium lead iodide (G-MAPbI ${ }_{3}$ ) thin film (Thickness $4 \mu \mathrm{m}$, $2.5 \mathrm{~cm} \times 2.5 \mathrm{~cm}$ on glass substrate) and (e) Fourier transform infrared spectroscopy comparison data of $\mathrm{MAI}, \mathrm{MAPbI}_{3}$ and $\mathrm{G}-\mathrm{MAPbI}_{3}$ (FTIR, SHIMADZU, IR Tracer-21, WMSRC, JU, Bangladesh).

Film thickness was measured $2 \mu \mathrm{m}, 4 \mu \mathrm{m}, 4.5 \mu \mathrm{m}, 5 \mu \mathrm{m}$ and $6 \mu \mathrm{m}$ by Surface Profilometer (Dektak XT-BCSIR, Dhanmondi, Dhaka, Bangladesh) of the pristine solution, G: $0.05 \mathrm{~g} / \mathrm{mole}, \mathrm{G}: 0.10 \mathrm{~g} / \mathrm{mole}, \mathrm{G}: 0.20 \mathrm{~g} / \mathrm{mole}$ and G: $0.30 \mathrm{~g} / \mathrm{mole}$ respectively. The UV-Visible absorption spectra are plotted together pristine perovskite solution and with different concentrations of graphene at 400 to 800 nm (Figure 3(a) and Figure 3(b)) to further confirm the proper powder crystal and thin film formation of the graphene composites perovskite onto ITO substrate. The as-deposited Graphene incorporated were studied and compared to the pristine $\mathrm{CH}_{3} \mathrm{NH}_{3} \mathrm{PbI}_{3}$ in terms of the reduction degree and the chemical 

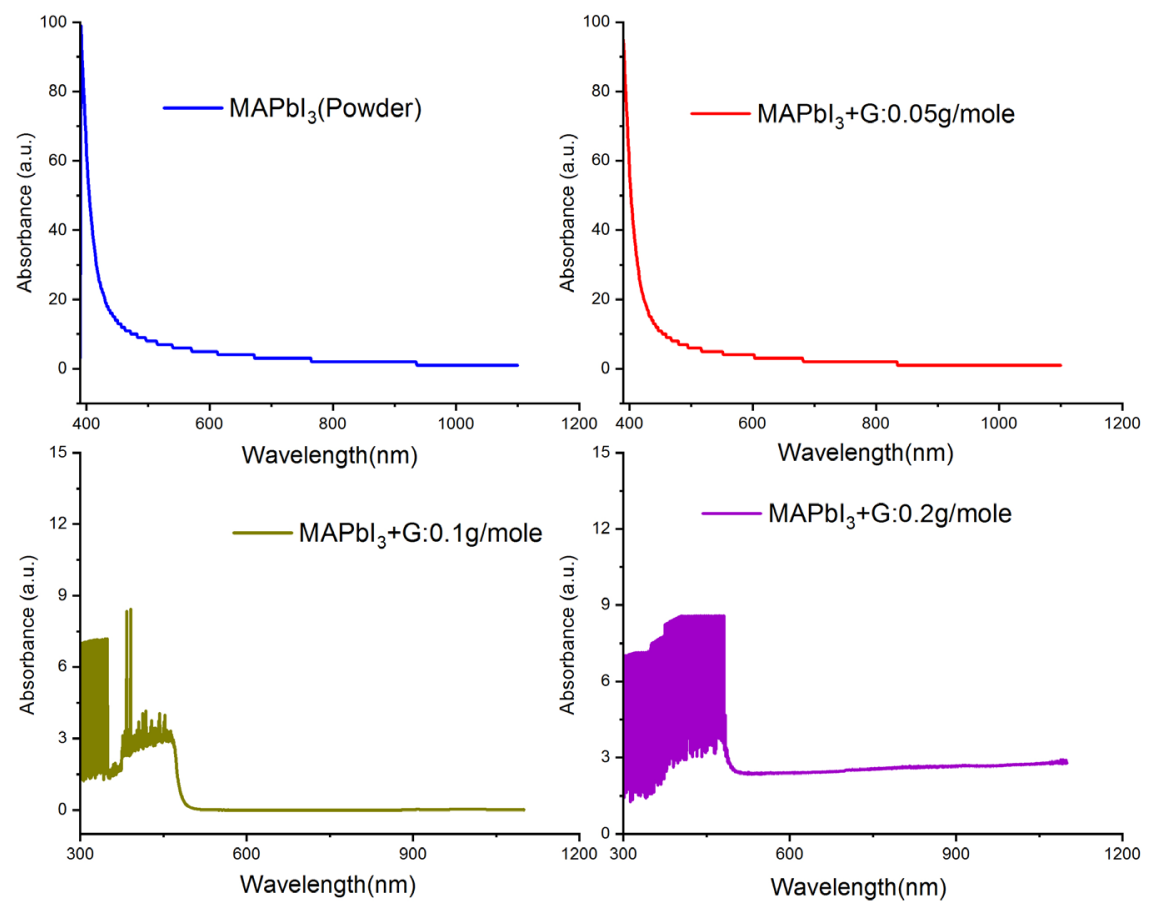

(a)
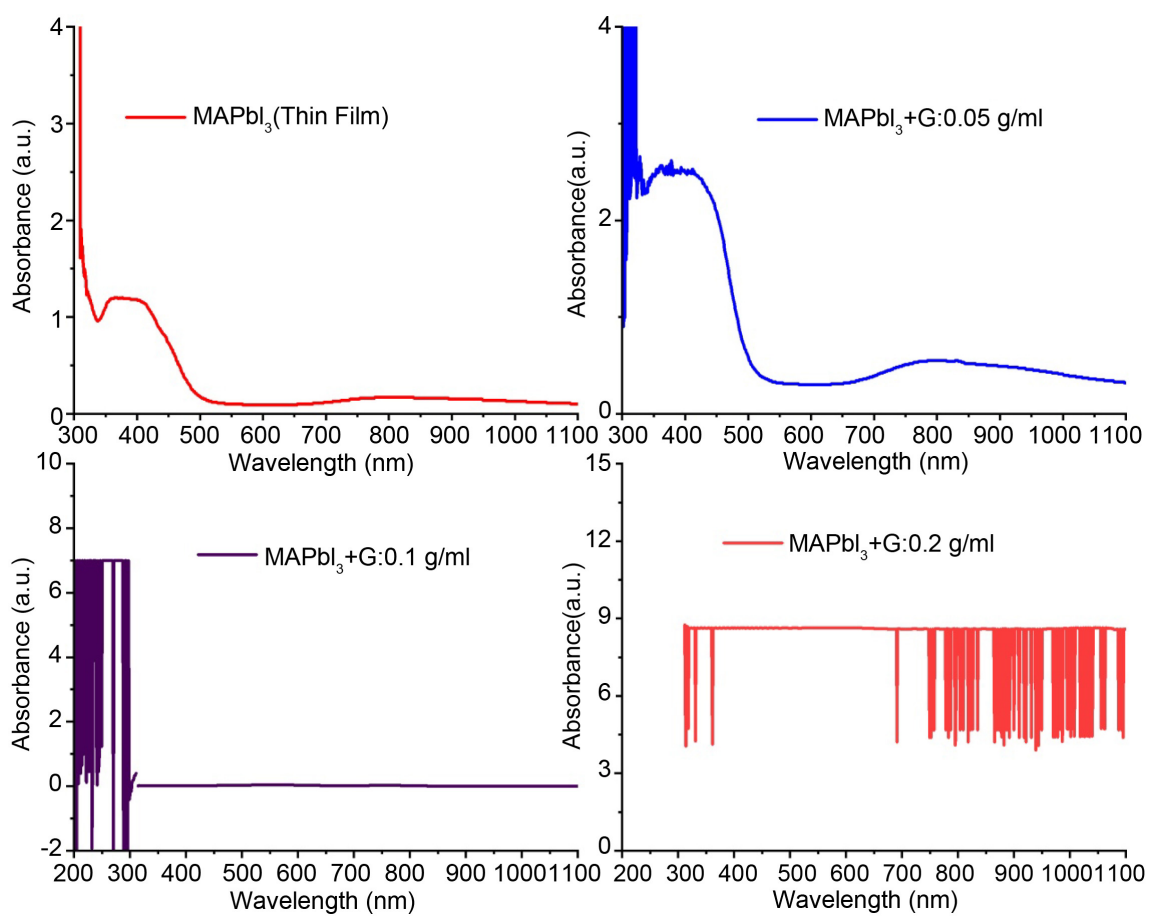

(b)

Figure 3. (a), (b) Absorption comparison of Methylammonium lead iodide $\left(\mathrm{MAPbI}_{3}\right)$ and Graphene incorporated in different concentration Methylammonium lead iodide $\left(\mathrm{G}-\mathrm{MAPbI}_{3}\right)$ powder crystal and thin-film respectively.

bonding by X-ray photoelectron spectroscopy (XPS) [36].

There are numerous peaks indicate different chemical bonds which confirm pristine perovskite whose graphene composition from these three FTIR 
(SHIMADZU, IR Tracer-21, WMSRC, JU, Bangladesh) curves spectrum of MAI, $\mathrm{MAPbI}_{3}$ and G-MAPbI (Figure 2(e)). Water molecule bond O-H stretching attributed at about $3510 \mathrm{~cm}^{-1}$ presented in all three curves due to the atmospheric synthesis process. The alkenes group of $\mathrm{C}-\mathrm{N}$ stretching is found in vibration mode $3120 \mathrm{~cm}^{-1}$ of $\mathrm{MAPbI}_{3}$ and $3118 \mathrm{~cm}^{-1}$ for $\mathrm{G}-\mathrm{MAPbI}_{3}$ but this curve is smaller than MAI. The bond C-H $\left(2960 \mathrm{~cm}^{-1}\right)$ stretching amines, C-H (1370 $\left.\mathrm{cm}^{-1}\right)$ bending alkenes, alkenes bending $\mathrm{NH}_{3}\left(1566-1570 \mathrm{~cm}^{-1}\right)$ and C-O (1630 $1635 \mathrm{~cm}^{-1}$ ) bending are attributed at both materials as-synthesized $\mathrm{MAPbI}_{3}$ and G-MAPbI ${ }_{3}$ (Table 2) [37].

\subsection{Optical Characterization of $\mathrm{CH}_{3} \mathrm{NH}_{3} \mathrm{PbI}_{3}$ and Graphene- $\mathrm{CH}_{3} \mathrm{NH}_{3} \mathrm{PbI}_{3}$}

Graphene incorporated $\mathrm{CH}_{3} \mathrm{NH}_{3} \mathrm{PbI}_{3}$ is proposed as an effectual way to enhance PCE\% of both PSCs by restraining the charge wounded stirring at the perovskite $/ \mathrm{TiO}_{2}$ interface, recovering the stability at the same time. Absorptions (Figure 3(a) and Figure 3(b)) are optimized (390 nm - $500 \mathrm{~nm}$ ) at Graphene $(0.05 \mathrm{~g} / \mathrm{mole})$ incorporation and reduced other Graphene concentration of perovskite investigating for both powder crystal and thin film. From thin film characterization i.e. the corresponding band gap is determined from Tauc plot (Graphene $0.05 \mathrm{~g} / \mathrm{mole}$ ) is reduced at $1.45 \mathrm{eV}$ to $1.32 \mathrm{eV}$ but it is larger about $2.90 \mathrm{eV}$ (Table 3, Figure 4(c) and Figure 4(d)) at powder crystal. As we can see from Figure 3(a), Figure 3(b) and Figure 4(a), Figure 4(b) graphene concentration absorptions that were $0.1 \mathrm{~g} / \mathrm{ml}, 0.2 \mathrm{~g} / \mathrm{ml}$ were no answer to the specifications for thin film and powder crystal, the following stage has not been used to develop the perovskite solar cell.

Table 2. Attribution of different Chemical bond of $\mathrm{CH}_{3} \mathrm{NH}_{3} \mathrm{PbI}_{3}$ and Graphene- $\mathrm{CH}_{3} \mathrm{NH}_{3}$ $\mathrm{PbI}_{3}$.

\begin{tabular}{ccccc}
\hline $\begin{array}{c}\text { MAPbI } \\
\text { Vibration } \\
\left(\mathrm{cm}^{-1}\right)\end{array}$ & $\begin{array}{c}\text { G-MAPbI } \\
\text { Vibration } \\
\left(\mathrm{cm}^{-1}\right)\end{array}$ & $\begin{array}{c}\text { Previously } \\
\text { reported [36] } \\
\text { vibration }\left(\mathrm{cm}^{-1}\right)\end{array}$ & Attributed & $\begin{array}{c}\text { MAPbI }_{3} \\
\text { Vibration } \\
\left(\mathrm{cm}^{-1}\right)\end{array}$ \\
\hline 3450 & 3510 & $3350-3500$ & O-H Stretch & 3450 \\
3120 & 3118 & 3175 & N-H Stretch & 3120 \\
2960 & 2960 & 2975 & C-H Stretch & 2960 \\
2700 & 2703 & $2400-2702$ & unidentified & 2700 \\
1635 & 1630 & 1717 & $\mathrm{C}^{-O}$ Bending & 1635 \\
1570 & 1566 & 1582 & $\mathrm{NH}_{3}$ bending & 1570 \\
1420 & 1408 & 1468 & $\mathrm{NH}_{3}$ bending & 1420 \\
1370 & 1370 & 1422 & $\mathrm{CH}_{3}$ bending & 1370 \\
1100 & 1100 & 1250 & $\mathrm{CH}_{3}-\mathrm{NH}_{3}$ rocking & 1100 \\
930 & 930 & 950 & $\mathrm{CH}_{3}-\mathrm{NH}_{3}$ rocking & 930 \\
\hline
\end{tabular}

*(using FTIR data by origin software). 


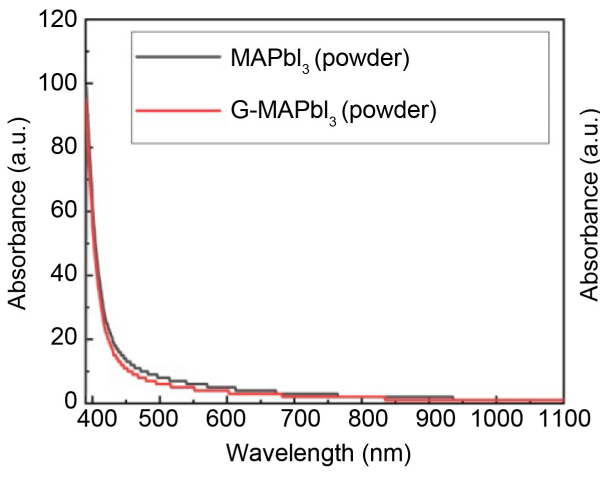

(a)

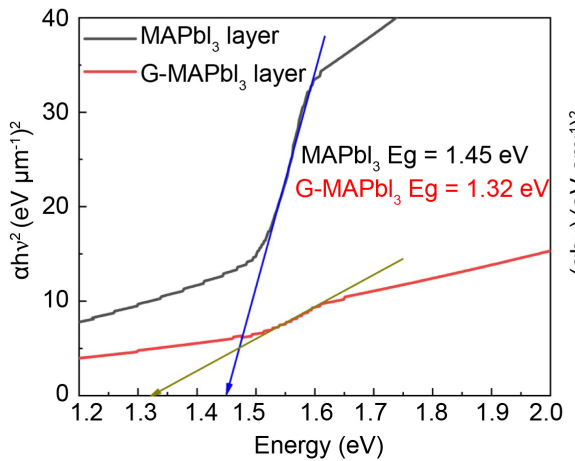

(c)

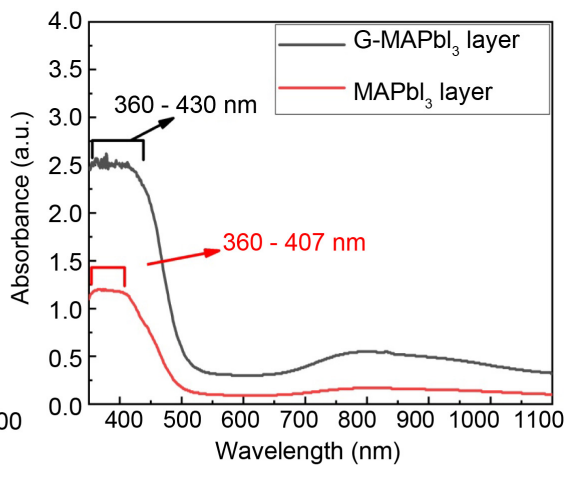

(b)

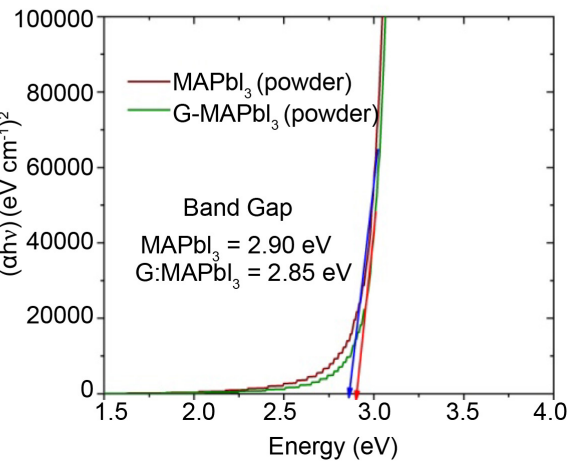

(d)

Figure 4. (a), (b) Absorption comparison of Methylammonium lead iodide $\left(\mathrm{MAPbI}_{3}\right)$ and optimized Graphene incorporated with Methylammonium lead iodide powder crystal and thin-film respectively, (c), (d) Band gap calculation of Methylammonium lead iodide $\left(\mathrm{MAPbI}_{3}\right)$ and optimized Graphene incorporated with Methylammonium lead iodide $\left(\mathrm{G}-\mathrm{MAPbI}_{3}\right)$ from Tauc Plot for powder crystal and thin-film respectively.

Table 3. Band gap calculation of $\mathrm{CH}_{3} \mathrm{NH}_{3} \mathrm{PbI}_{3}$ and Graphene- $\mathrm{CH}_{3} \mathrm{NH}_{3} \mathrm{PbI}_{3}$ from Tauc Plot (UV-Vis Spectroscopy, Anlytikjena AG Model-05 PC controlled Double Beam Spectrophotometer, WMSRC, JU, Bangladesh).

\begin{tabular}{ccccc}
\hline Materials & $\begin{array}{c}\mathrm{MAPbI}_{3} \\
\text { (thin film) }\end{array}$ & $\begin{array}{c}\mathrm{MAPbI}_{3} \\
\text { (G: } 0.05 \mathrm{~g} / \mathrm{mole}) \\
\text { (thin film) }\end{array}$ & $\begin{array}{c}\mathrm{MAPbI}_{3} \\
\text { (powder) }\end{array}$ & $\begin{array}{c}\mathrm{MAPbI}_{3} \\
\text { (G: } 0.05 \mathrm{~g} / \mathrm{mole}) \\
\text { (powder) }\end{array}$ \\
\hline Band Gap (eV) & 1.45 & 1.32 & 2.90 & 2.85 \\
\hline
\end{tabular}

\subsection{Current-Voltage Measurement}

At high humidity $(99 \% \mathrm{RH})$ current-voltage (I-V) curves were obtained after revealing the $\mathrm{CH}_{3} \mathrm{NH}_{3} \mathrm{PbI}_{3}$ solar cell for different graphene composition. The swift decline in the open circuit-voltage and short-circuit current density of the undefended $\mathrm{CH}_{3} \mathrm{NH}_{3} \mathrm{PbI}_{3}$ cells showed a (Figure 5(d), Figure 5(e)) with time. After 30 days of revelation to moisture, no photovoltaic behavior is seen from the cells but Graphene incorporated PSCs still work up to 150 days (Figure 5(b)) Mounting the thickness by overlayer $(\sim 4 \mu \mathrm{m})$ stability of the cells from moistures are improved encapsulated with graphene/ $\mathrm{CH}_{3} \mathrm{NH}_{3} \mathrm{PbI}_{3}$. Graphene solution with pristine perovskite solar cell using spin coating three times mentioned little variation in cell performance with time but in a different composition 
of graphene deposited solar cells continuously exposed longtime to high humidity. Water molecules have to move before they can contact the $\mathrm{CH}_{3} \mathrm{NH}_{3} \mathrm{PbI}_{3}$ crystal tortuosity in the path rises with increasing thickness of the composite. The best performing cell with a graphene composite demonstrated a photocurrent $0.1 \mathrm{~mA} \cdot \mathrm{cm}^{-2}$ (Table 4 supporting information) and an open-circuit voltage $0.368 \mathrm{~V}$ (Figure $5(\mathrm{e})$ ). We look forward to the perovskite degradation regardless of the series $\left(\mathrm{R}_{\mathrm{S}}\right)$ and $\operatorname{shunt}\left(\mathrm{R}_{\mathrm{SH}}\right)$ resistances mechanism is calculated to

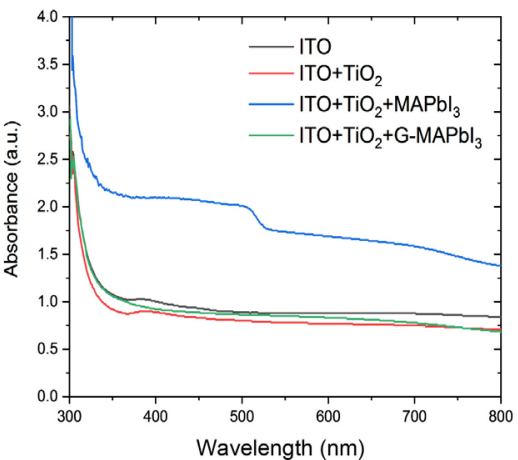

(a)

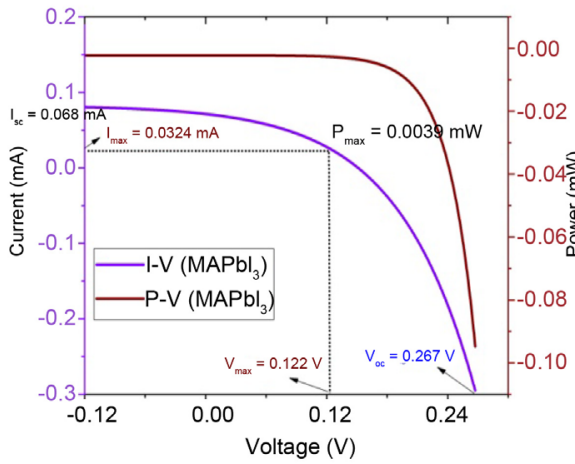

(d)

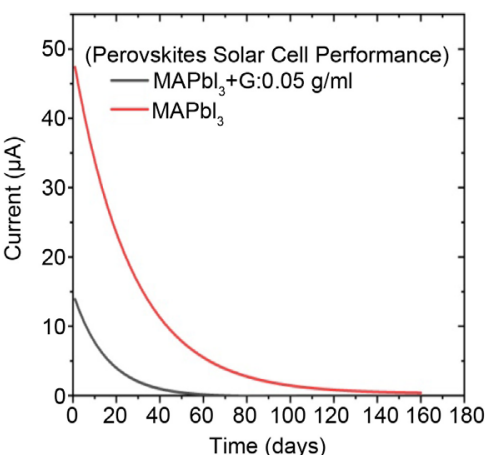

(b)

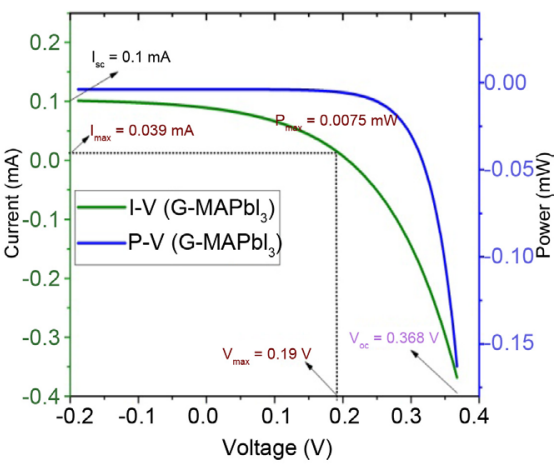

(e)

Figure 5. (a) Absorption comparison of ITO, Titanium Di-oxide deposited on ITO, Methylammonium lead iodide $\left(\mathrm{MAPbI}_{3}\right)$, Titanium Di-oxide deposited on ITO and Graphene incorporated Methylammonium lead iodide (G-MAPbI $)_{3}$ thin film, (b) Ageing effect measuring of fabricated PSCs in daylight, (c) Current-Voltage-Power of Methylammonium lead iodide $\left(\mathrm{MAPbI}_{3}\right)$, (d) Graphene incorporated Methylammonium lead iodide $\left(\mathrm{G}-\mathrm{MAPbI}_{3}\right)$ based solar cells performance (Solar Simulator, $1.5 \mathrm{AM}$ at $25^{\circ} \mathrm{C}$ and power $1 \mathrm{KW}$, BCSIR, Dhaka, Bangladesh) and (e) As fabricated devices (CMP Lab, Physics Dept. JU, Bangladesh).

Table 4. Perovskites solar cells performance using $\mathrm{CH}_{3} \mathrm{NH}_{3} \mathrm{PbI}_{3}$ and Graphene- $\mathrm{CH}_{3} \mathrm{NH}_{3} \mathrm{PbI}_{3}$ perovskites materials (1.5 AM at $25^{\circ} \mathrm{C}$ and power $1 \mathrm{KW}, \mathrm{BCSIR}$, Dhaka, Bangladesh).

\begin{tabular}{cccccc}
\hline Solar Cells & $\begin{array}{c}\text { Current } \\
\text { density } \\
\left(\mathrm{mA} \cdot \mathrm{cm}^{-2}\right)\end{array}$ & $\begin{array}{c}\text { Fill Factor } \\
(\mathrm{FF} \%)\end{array}$ & $\begin{array}{c}\text { Open } \\
\text { Circuit-Voltage } \\
(\mathrm{mV})\end{array}$ & $\begin{array}{c}\text { Short } \\
\text { Circuit-Current } \\
(\mathrm{mA})\end{array}$ & $\begin{array}{c}\text { Power } \\
\text { Conversion } \\
\text { Efficiency } \\
(\mathrm{PCE} \%)\end{array}$ \\
\hline $\mathrm{MAPbI}_{3}$ & 0.420 & 38.4 & 267 & 0.086 & 0.0069 \\
$\mathrm{G}_{-} \mathrm{MAPbI}_{3}$ & 0.420 & 47.2 & 368 & 0.1 & 0.017 \\
\hline
\end{tabular}


investigate the effect of graphene protective coating on the electrical performance of the PSCs. Graphene concentration reveals lower recombination losses than lead iodide that performs of the device can be optimized. Due to the low conductivity of ITO when compared with lead iodide devices fabricated utilizing graphite itself as the HTL illustrated lower short circuit current $68 \mu \mathrm{A}$ and open-circuit voltage of $368 \mathrm{mV}$ (supporting information, Figure 5(d), Figure $5(e))$. Depend on different concentrations of graphene incorporation with $\mathrm{CH}_{3} \mathrm{NH}_{3} \mathrm{PbI}_{3}$ PSCs, photocurrents are varied due to the graphene composite averting the direct contact of $\mathrm{TiO}_{2}(\mathrm{ETL})$ and performing as a buffer layer and the lead iodide.

Another degradation of the perovskite layer was investigated due to the transmission of moisture and oxygen into the perovskite which is machinery to be identical though shunt and series resistances of the cells were present [38]. Therefore, high-efficiency cells could be achieved with higher shunt resistances and lower series (compared to best-performing cells). Without any shielding graphene layer, the PSC device demonstrated shunt resistance $\left(\mathrm{R}_{\mathrm{SH}}\right) 18.7 \mathrm{~K} \Omega$ and series resistance $\left(R_{s}\right) 20.6 \mathrm{~K} \Omega$. The device one with graphene $(0.05 \mathrm{~g} / \mathrm{mole})$ composite revealed a reduced in both $\mathrm{R}_{S H}$ and $\mathrm{R}_{S}$ to a $16.6 \mathrm{~K} \Omega$ and $19.3 \mathrm{~K} \Omega$ respectively. Compared to other graphene composition lead-based PSCs $\mathrm{R}_{S \mathrm{SH}}$ and $R_{S}$ resistances are growing concerning the second one. The perovskite a larger nano amalgamated is twisted in which the volume of unit cell augmented 776 $(\AA)^{3}$ to $2003(\AA)^{3}$ (Table 1 supporting information) owing to graphene incorporation. Beside the electrons of $\mathrm{TiO}_{2}$ and holes of $\mathrm{PbI}_{2}$ illustrated the way to the lower shunt resistance $\left(\mathrm{R}_{\mathrm{SH}}\right)$ due to $\mathrm{PbI}_{2}$ may arrive in contact with the $\mathrm{TiO}_{2}$ [39].

The best performance of perovskite device showed (Figure 5(e)) power conversion efficiency (PCE\%) $0.017 \%\left(1.5 \mathrm{AM}\right.$ at $25^{\circ} \mathrm{C}$ and power $1 \mathrm{KW}, \mathrm{BCSIR}$, Dhaka, Bangladesh), with Current density $\mathrm{J}_{\mathrm{sc}}=420 \mu \mathrm{A} / \mathrm{cm}^{2}, \mathrm{~V}_{\mathrm{oc}}=368 \mathrm{mV}$ and $\mathrm{FF}=47.2 \%$ (Table 4 supporting information). Devices were investigated in a range $-5 \mathrm{~V}$ to $+5 \mathrm{~V}$ for dark current renovating behavior of cell operating under the dark condition where the high dark current was established (Figure 5(d), Figure 5(e)) at survival of high outflow current may be due to the undeviating construct contact between the graphite $(\mathrm{HTL})$ and $\mathrm{TiO}_{2}$. Under atmospheric conditions the dispensation of $\mathrm{CH}_{3} \mathrm{NH}_{3} \mathrm{PbI}_{3}$ cells reviewed with graphene composite which could consent to the high moisture impermeability. A main strategy to reduce the cost of production of perovskite solar cells for rolling-to-roll coated plate sandwiches. For the long time stability of PSCs similar perception can also be effective in the design of different materials for further research.

\subsection{Synthesis Process}

Two arms flask was filled with methylamine $20 \mathrm{ml}$ adding hydrochloric acid 17 $\mathrm{ml}$ (32\% in water, from Merck) drop wise with methylamine solution (40\% mono, from Qualikems) and Methylammonium iodide $\left(\mathrm{CH}_{3} \mathrm{NH}_{2} \mathrm{I}: \mathrm{MAI}\right)$ was obtained at $\left(8^{\circ} \mathrm{C}-10^{\circ} \mathrm{C}\right)$ for $1 \mathrm{~h}$ with stirring. MAI was potted in an ice bath for 
$2 \mathrm{hrs}$ and preserved on an oven suspiciously removing the solvent at $60^{\circ} \mathrm{C}$. Using diethyl ether (from Merck) the crystalline $\mathrm{CH}_{3} \mathrm{NH}_{3} \mathrm{I}$ was uncontaminated several times and dried light black powder of $\mathrm{CH}_{3} \mathrm{NH}_{3} \mathrm{I}$ was collected. For the synthesis of perovskite $\mathrm{CH}_{3} \mathrm{NH}_{3} \mathrm{PbI}_{3}$ precursor, $0.794 \mathrm{~g} \mathrm{CH}_{3} \mathrm{NH}_{3} \mathrm{I}$ was dissolved into $5 \mathrm{~mL} \mathrm{~N}, \mathrm{~N}$-dimethylformamide and $2.305 \mathrm{~g} \mathrm{PbI}_{2}$ was dissolved into $5 \mathrm{~mL} \mathrm{~N}$, $\mathrm{N}$-dimethylformamide (1:1) separately [40]. Then the prepared solutions were added and a light yellow solution of $\mathrm{CH}_{3} \mathrm{NH}_{3} \mathrm{PbI}_{3}$ was obtained (Figure 2(a)). Graphene was prepared according to a modified Hummer's Method and it was added at concentrations $0.05 \mathrm{~g} \cdot \mathrm{ml}^{-1}, 0.10 \mathrm{~g} \cdot \mathrm{ml}^{-1}, 0.20 \mathrm{~g} \cdot \mathrm{ml}^{-1}$ at 45 mass\% with pristine perovskite (Figure 2(b)) solution to obtain G-MAPbI 3 .

\subsection{Device Fabrication}

Using PEG (Polyethylene Glycol), $\mathrm{TiO}_{2}$ and Distilled water respectively 1:3:20 ratios mixed at high humidity $(99 \% \mathrm{RH})$ to obtain $\mathrm{TiO}_{2}$ solution. Proper dispersion of $\mathrm{TiO}_{2}$ solution to deposit uniform film PEG typically used [41]. Dr. Blade's method was followed to deposit $\mathrm{TiO}_{2}$ film on pre-cleaned ITO (ITOs were cleaned by ultrasonic bath sequentially in normal distilled water, ethanol and acetone, pursued by drying in an oven at $60^{\circ} \mathrm{C}$ ). For better film stickiness substrates were transferred into a furnace to anneal at $400^{\circ} \mathrm{C}$ for 25 mins. Pristine solutions were deposited on coated ITO by spin-coater (2000 rpm for the $30 \mathrm{~s}$ ) and heating $80^{\circ} \mathrm{C}$ until crystal growth under atmospheric condition. Then, the substrates were sandwiched together by another graphite coated ITO (Figure $5(\mathrm{c}))$.

\subsection{Instruments and Characterizations}

To analysis light absorption, transmittance, band gap calculation and co-efficient of absorbance of materials, UV-Vis Spectrophotometer (Model: UVS-2800 at a wavelength range of $200 \mathrm{~nm}-1100 \mathrm{~nm}$ ) were used. Determination of crystallite size, lattice parameters i.e. unit cell volume, edge length, lattice system, crystallinity and uniformity of crystal of perovskites X-Ray Diffraction (XRD) data were collected on GBC EMMA X-ray diffractometer ( $\mathrm{Cu} \mathrm{K} \alpha$ radiation, $\lambda=1.54$ $\AA$ ) at WMSRC, Jahangirnagar University, Bangladesh. The scanning angular range was $5^{\circ} \leq 2 \theta \leq 50^{\circ}$ to get possible fundamental picks for each sample. The measuring film thickness of perovskites, $\mathrm{TiO}_{2}$, graphite and ITO, Surface Profilometer (Dektak XT-BCSIR, Dhanmondi, Dhaka, Bangladesh) was used. FTIR (SHIMADZU, IR Tracer-21, wave number $400 \mathrm{~cm}^{-1}$ to $4000 \mathrm{~cm}^{-1}$, WMSRC, JU, Bangladesh) was used to ensure the chemical of the bond which are present on samples. To certify the performance of perovskite solar cells, Solar Simulator (IEC 60904-9 Edition2 and ASTM E927-10 standards, BCSIR, Bangladesh) under an AM1.5G filter at $100 \mathrm{~mW} \cdot \mathrm{cm}^{-2}$ was used.

\section{Conclusion}

We demonstrated a cost-effective perovskite solar cell using first time ITO as a 
counter electrode replacing highly cost metal $\mathrm{Au} / \mathrm{Ag}$ under ambient condition. The UV-Visibility range of perovskites shows the connection between absorbance and wavelength, indicating very low photosensitivity. Compared to pristine cell graphene incorporation, the excellent stability of up to 150 days of photovoltaic output, as well as the fill factor, increases. Another best work is to reduce the band gap of perovskite $1.32 \mathrm{eV}$ and optimize the graphene concentration for light absorption as well as co-efficient. As a multifunctional coating facilitated charge-carrier transport graphene/perovskite composite has been established while at the same time affording an impermeable seal to moisture, demonstrating confirmation of perception combination coating for improving cell stability.

\section{Authors Contributions}

SSA, OR and KH urbanized the proposal of using graphite as an HTM. SSA and $\mathrm{KH}$ contributed equally to this work. SSA and UH prepared the experimental diagram and fulfilled the experiments. All the authors evaluated to co-writer and conversed about the data of the manuscript. SSA, OR and KH build up the idea of using graphene as with perovskites.

\section{Acknowledgements}

SSA recognized to UGC based research fellowship. The authors acknowledged Shahriar Bashar, Principle Scientific Officer, BCSIR, Dhaka, Bangladesh and Khairul Islam, Scientific Officer, WMSRC, Jahangirnagar University for performing PCE\% measurements on the perovskite solar cells and the CMP Lab, JU for Renewable Energy Research for working facilities.

\section{Conflicts of Interest}

The authors declare no conflicts of interest regarding the publication of this paper.

\section{References}

[1] Ashrafi, S., Hossain, K., Ahmed, F., Hossain, A. and Rahman, O. (2020) Fabrication and Characterization of Graphene Incorporated $\mathrm{Cu}$ Based Perovskite in Application of Perovskite Solar Cell under Ambient Condition. Advances in Materials Physics and Chemistry, 10, 1-16. https://doi.org/10.4236/ampc.2020.101001

[2] Zhou, N., López-Puente, V., Wang, Q. Polavarapu, L. Pastoriza-Santos, I. and Xu, Q.-H. (2015) Plasmon-Enhanced Light-Harvesting: Applications in Enhanced Photocatalysis, Photodynamic Therapy and Photovoltaics. RSC Advances, 5, 29076-29097. https://doi.org/10.1039/C5RA01819F

[3] Vicente, A.T., Araújo, A., Mendes, M.J., Nunes, D., Oliveira, M.J., Sanchez-Sobrado, O., Ferreira, M.P., Águas, H., Fortunato, E. and Martins, R. (2018) Multifunctional Cellulose-Paper for Light-Harvesting and Smart Sensing Applications. Journal of Materials Chemistry C, 6, 3143-3181. https://doi.org/10.1039/C7TC05271E

[4] Cai, W.Z., Xiong, G. and Yong, C. (2010) Polymer Solar Cells: Recent Development 
and Possible Routes for Improvement in the Performance. Solar Energy Materials and Solar Cells, 94, 114-127. https://doi.org/10.1016/j.solmat.2009.10.005

[5] Chen, J.W. and Yong, C. (2009) Development of Novel Conjugated Donor Polymers for High-Efficiency Bulk-Heterojunction Photovoltaic Devices. Accounts of Chemical Research, 42, 1709-1718. https://doi.org/10.1021/ar900061z

[6] Lidow, A., de Rooij, M., Strydom, J., Reusch, D. and Glaser, J. (2019) GaN Transistors for Efficient Power Conversion. John Wiley \& Sons, Hoboken. https://doi.org/10.1002/9781119594406

[7] Vadiyar, M.M., Bhise, S.C., Kolekar, S.S., Chang, J.-Y., Ghulec, K.S. and Ghule, A.V. (2016) Low-Cost Flexible 3-D Aligned and Cross-Linked Efficient $\mathrm{ZnFe}_{2} \mathrm{O}_{4} \mathrm{Na}$ no-Flakes Electrode on Stainless Steel Mesh for Asymmetric Supercapacitors. Journal of Materials Chemistry A, 4, 3504-3512.

https://doi.org/10.1039/C5TA09022A

[8] Dechan, A. and Krebs, F.C. (2013) Flexible ITO-Free Polymer Solar Cells. Journal of Applied Polymer Science, 129, 1-14. https://doi.org/10.1002/app.38854

[9] Smith, I.C., Hoke, E.T., Solis-Ibarra, D., McGehee, M.D. and Karunadasa, H.I. (2014) A Layered Hybrid Perovskite Solar-Cell Absorber with Enhanced Moisture Stability. Angewandte Chemie International Edition, 53, 11232-11235. https://doi.org/10.1002/anie.201406466

[10] Raven, J. (2000) The Raven's Progressive Matrices: Change and Stability over Culture and Time. Cognitive Psychology, 41, 1-48. https://doi.org/10.1006/cogp.1999.0735

[11] Sonenshein, S. (2010) We're Changing-Or Are We? Untangling the Role of Progressive, Regressive, and Stability Narratives during Strategic Change Implementation. Academy of Management Journal, 53, 477-512. https://doi.org/10.5465/amj.2010.51467638

[12] Christians, J.A., Schulz, P., Tinkham, J.S., Schloemer, T.H., Harvey, S.P., Tremolet de Villers, B.J., Sellinger, A., Berry, J.J. and Luther, J.M. (2018) Tailored Interfaces of Unencapsulated Perovskite Solar Cells for $>1,000$ Hour Operational Stability. Nature Energy, 3, 68-74. https://doi.org/10.1038/s41560-017-0067-y

[13] Grancini, G., Roldán-Carmona, C., Zimmermann, I., Mosconi, E., Lee, X., Martineau, D., Narbey, S., Oswald, F., De Angelis, F., Graetzel, M. and Khaja Nazeeruddin, M. (2017) One-Year Stable Perovskite Solar Cells by 2D/3D Interface Engineering. Nature Communications, 8, Article No. 15684.

https://doi.org/10.1038/ncomms15684

[14] Hagfeldt, A. and Michael, G. (1995) Light-Induced Redox Reactions in Nanocrystalline Systems. Chemical Reviews, 95, 49-68.

https://doi.org/10.1021/cr00033a003

[15] Ng, M., Fleming, T., Robinson, M., Thomson, B., Graetz, N., Margono, C., et al. (2014) Global, Regional, and National Prevalence of Overweight and Obesity in Children and Adults during 1980-2013: A Systematic Analysis for the Global Burden of Disease Study 2013. The Lancet, 384, 766-781.

https://doi.org/10.1016/S0140-6736(14)60460-8

[16] Peng, X.Y. and En, Y.D. (2012) Novel Synthesis of $\mathrm{TiO}_{2}$ Nanocrystals Induced by Nanocrystal Cellulose. In: Xu, X.P., Cadoni, E., Cheng, Y.S., Chinakhov, D.A., Dodun, O., Gogu, G., Krenický, T. and Zulkifli, R., Eds., Applied Mechanics and Materials, Vol. 117-119, Trans Tech Publications Ltd., Switzerland, 944-948.

https://doi.org/10.4028/www.scientific.net/AMM.117-119.944

[17] Oman, Z.U.A.S. and Nuryatini, H. (2013) Synthesis, Characterization and Proper- 
ties of $\mathrm{CeO}_{2}$-Doped $\mathrm{TiO}_{2}$ Composite Nanocrystals. Materials Science, 19, 443-447. https://doi.org/10.5755/j01.ms.19.4.2732

[18] Kong, L.Y. and Ren, X.T. (2015) Artemisinin, a Miracle of Traditional Chinese Medicine. Natural Product Reports, 32, 1617-1621.

https://doi.org/10.1039/C5NP00133A

[19] Singh, T. and Miyasaka, T. (2018) Stabilizing the Efficiency Beyond 20\% with a Mixed Cation Perovskite Solar Cell Fabricated in Ambient Air under Controlled Humidity. Advanced Energy Materials, 8, Article ID: 1700677. https://doi.org/10.1002/aenm.201700677

[20] Deepa, M., Salado, M., Calio, L., Kazim, S., Shivaprasadc, S.M. and Ahmad, S. (2017) Cesium Power: Low Cs+ Levels Impart Stability to Perovskite Solar Cells. Physical Chemistry Chemical Physics, 19, 4069-4077. https://doi.org/10.1039/C6CP08022G

[21] Misture, S.T. (2003) Large-Volume Atmosphere-Controlled High-Temperature X-Ray Diffraction Furnace. Measurement Science and Technology, 14, 1091. https://doi.org/10.1088/0957-0233/14/7/326

[22] Brugger, C.R., Johnston, A.D. and Cashman, K.V. (2003) Phase Relations in Silicic Systems at One-Atmosphere Pressure. Contributions to Mineralogy and Petrology, 146, 356-369. https://doi.org/10.1007/s00410-003-0503-9

[23] Chen, C.-P., Chen, Y.-D. and Chuang, S.-C. (2011) High-Performance and Highly Durable Inverted Organic Photovoltaics Embedding Solution-Processable Vanadium Oxides as an Interfacial Hole-Transporting Layer. Advanced Materials 23, 3859-3863. https://doi.org/10.1002/adma.201102142

[24] Hutter, E.M., Eperon, G.E., Stranks, S.D. and Savenije, T.J. (2015) Charge Carriers in Planar and Mesostructured Organic-Inorganic Perovskites: Mobilities, Lifetimes, and Concentrations of Trap States. The Journal of Physical Chemistry Letters, 6, 3082-3090. https://doi.org/10.1021/acs.jpclett.5b01361

[25] Wojtoniszak, M., Chen, X.C., Kalenczuk, R.J., Wajda, A., Łapczuk, J., Kurzewski, M., Drozdzik, M., Chu, P.K. and Borowiak-Palen, E. (2012) Synthesis, Dispersion, and Cytocompatibility of Graphene Oxide and Reduced Graphene Oxide. Colloids and Surfaces B: Biointerfaces, 89, 79-85.

https://doi.org/10.1016/j.colsurfb.2011.08.026

[26] Zhao, C.Q., Xu, X.C., Chen, J. and Yang, F.L. (2013) Effect of Graphene Oxide Concentration on the Morphologies and Antifouling Properties of PVDF Ultrafiltration Membranes. Journal of Environmental Chemical Engineering, 1, 349-354. https://doi.org/10.1016/j.jece.2013.05.014

[27] Christensen, J., Manjavacas, A., Thongrattanasiri, S., Koppens, F.H.L. and Javier García de Abajo, F. (2012) Graphene Plasmon Waveguiding and Hybridization in Individual and Paired Nanoribbons. ACS Nano, 6, 431-440.

https://doi.org/10.1021/nn2037626

[28] Kim, H.-K., Kim, Y.N., Kim, K.S., Jeong, H.Y., Jang, A.-R., Han, S.H., Yoon, D.H., Suh, K.S., Shin, H.S., Kim, T.Y. and Yang, W.S. (2013) Flexible Thermochromic Window Based on Hybridized $\mathrm{VO}_{2} /$ Graphene. ACS Nano, 7, 5769-5776. https://doi.org/10.1021/nn400358x

[29] Lin, C.-T., Loan, P.T.K., Chen, T.-Y., Liu, K.-K., Chen, C.-H., Wei, K.-H. and Li, L.-J. (2013) Label-Free Electrical Detection of DNA Hybridization on Graphene Using Hall Effect Measurements: Revisiting the Sensing Mechanism. Advanced Functional Materials, 23, 2301-2307. https://doi.org/10.1002/adfm.201202672

[30] Li, Y., Cooper, J., Liu, W., Sutter-Fella, C.M., Amani, M., Beeman, J.W., Javey, A., 
Ager, J.W., Liu, Y., Toma, F.M. and Sharp, I.D. (2016) Defective $\mathrm{TiO}_{2}$ with High Photoconductive Gain for Efficient and Stable Planar Heterojunction Perovskite Solar Cells. Nature Communications, 7, Article No. 12446. https://doi.org/10.1038/ncomms12446

[31] Chen, M.-W., Chen, C.-Y., Lien, D.-H., Ding, Y. and He, Jr.-H. (2010) Photoconductive Enhancement of Single $\mathrm{ZnO}$ Nanowire through Localized Schottky Effects. Optics Express, 18, 14836-14841. https://doi.org/10.1364/OE.18.014836

[32] Mar, A., Loubriel, G.M., Zutavern, F.J., O’Malley, M.W., Helgeson, W.D., Brown, D.J., et al. (2000) Doped Contacts for High-Longevity Optically Activated, High-Gain GaAs Photoconductive Semiconductor Switches. IEEE Transactions on Plasma Science, 28, 1507-1511. https://doi.org/10.1109/27.901223

[33] Lee, Y.T. and More, R.M. (1984) An Electron Conductivity Model for Dense Plasmas. The Physics of Fluids, 27, 1273-1286. ttps://doi.org/10.1063/1.864744

[34] Krisko, A.J., Myli, K.B. and Burrows, K.J. (2011) Photocatalytic Coatings Having improved Low-Maintenance Properties. U.S. Patent No. 7862910.

[35] Wu, Y.Q., Wang, P., Zhu, X.L., Zhang, Q.Q., Wang, Z.Y., Liu, Y.Y., Zou, G.Z., Dai, Y., Whangbo, M.-H., Huang, B.B. (2018) Composite of $\mathrm{CH}_{3} \mathrm{NH}_{3} \mathrm{PbI}_{3}$ with Reduced Graphene Oxide as a Highly Efficient and Stable Visible-Light Photocatalyst for Hydrogen Evolution in Aqueous HI Solution. Advanced Materials, 30, Article ID: 1704342. https://doi.org/10.1002/adma.201704342

[36] Ito, S., et al. (2014) Carbon-Double-Bond-Free Printed Solar Cells from $\mathrm{TiO}_{2} / \mathrm{CH}_{3} \mathrm{NH}_{3} \mathrm{PbI}_{3} / \mathrm{CuSCN} / \mathrm{Au}$ : Structural Control and Photoaging Effects. ChemPhysChem, 15, 1194-1200. https://doi.org/10.1002/cphc.201301047

[37] Corrales, T., Catalina, F., Peinado, C., Allen, N.S. and Fontan, E. (2002) Photooxidative and Thermal Degradation of Polyethylenes: Interrelationship by Chemiluminescence, Thermal Gravimetric Analysis and FTIR Data. Journal of Photochemistry and Photobiology A: Chemistry, 147, 213-224. https://doi.org/10.1016/S1010-6030(01)00629-3

[38] Mahmud, M.A., Elumalai, N.K., Upama, M.B., Wang, D., Chan, K.H., Wright, M., $\mathrm{Xu}, \mathrm{C}$., Haque, F. and Uddin, A. (2017) Low Temperature Processed ZnO Thin Film as Electron Transport Layer for Efficient Perovskite Solar Cells. Solar Energy Materials and Solar Cells, 159, 251-264. https://doi.org/10.1016/j.solmat.2016.09.014

[39] Gao, Q.Q., Yang, S.W., Lei, L., Zhang, S.D. , Cao, Q.P., Xie, J.J., Li. J.Q., Liu, Y. (2015) An Effective $\mathrm{TiO}_{2}$ Blocking Layer for Perovskite Solar Cells with Enhanced Performance. Chemistry Letters, 44, 624-626. https://doi.org/10.1246/cl.150049

[40] Liu, J.Y., Xue, Y.Z., Wang, Z.Y., Xu, Z.-Q., Zheng, C.X., Weber, B., Song, J.C., Wang, Y.S., Lu, Y.R., Zhang, Y.P. and Bao, Q.L. (2016) Two-Dimensional $\mathrm{CH}_{3} \mathrm{NH}_{3} \mathrm{PbI}_{3}$ Perovskite: Synthesis and Optoelectronic Application. ACS Nano, 10, 3536-3542. https://doi.org/10.1021/acsnano.5b07791

[41] Song, H.C., Shao, J.H., He, Y.L., Liu, B. and Zhong, X.Q. (2012) Natural Organic Matter Removal and Flux Decline with PEG-TiO 2 -Doped PVDF Membranes by the Integration of Ultrafiltration with Photocatalysis. Journal of Membrane Science, 405-406, 48-56. https://doi.org/10.1016/j.memsci.2012.02.063 